\title{
MARKETING OF RIJEKA MUSEUMS: CURRENT PRACTICES AND FUTURE DIRECTIONS
}

\author{
Đurđana Ozretić Došen \\ Emanuela Cvetinović \\ Tanja Komarac
}

https://doi.org//10.20867/tosee.06.37

\begin{abstract}
Purpose - The paper is dedicated to the marketing of Rijeka museums. It presents the research that encompassed a) museum professionals' marketing knowledge and skills and their implementation in practice b) core and additional services offered by museums c) museum professionals' opinions and attitudes about the new trends in museum marketing.

Methodology - Exploratory research was conducted. Data for the theoretical foundations were collected from secondary scientific sources and by searching the websites, social networks, and promotional materials. Qualitative research in the form of in-depth, semi-structured personal interviews with key informants was performed to collect primary data.

Findings - The level of familiarity with the services marketing in Rijeka museums was low, pointing to a lack of marketing professionals. Nevertheless, the need for marketing was recognised, and museums were striving to implement some generic marketing activities. The core services (exhibitions and/or collections of materials) showed predominant product orientation, with insufficient orientation on a visitor. Opinions and attitudes of interviewees on museum marketing trends were positive. However, museums could not include new content despite wishes due to the lack of capacity. Furthermore, the legal frame prevented expanding the offer of a souvenir shop. Contribution - Although the research was conducted before the onset of the pandemic, the paper provides theoretical insights and practical suggestions, which could help academics and professionals to understand better and deal with the potential opportunities and threats in museum marketing in the dramatically changing environmentns.
\end{abstract}

Keywords: museum marketing, museum professionals, exploratory research, Rijeka.

\section{INTRODUCTION}

To be successfully applied in museums as specific institutions of culture and art, marketing needs to be adapted to multiple elements that include the type of museum, its size, variety of collections, nature of exhibitions (permanent or temporary), and resources - human, spatial, financial. In these efforts, the critical factor is the willingness of museum professionals to accept the marketing philosophy and business concept as a starting point for planning and implementing museum services, which is not contrary or in a collision to the preservation of heritage, i.e., with the custodial approach that is often cited as a priority task and museum's function (Gilmore and Rentschler 2002; Camarero, Garrido and Vicente 2015).

This paper builds upon previous research on museum professionals' attitudes about marketing. The goal is to reveal and critically analyse Rijeka museum professionals' attitudes about: 
ToSEE - Tourism in Southern and Eastern Europe, Vol. 6, pp. 545-558, 2021.

Đ. Ozretić Došen, E. Cvetinović, T Komarac: MARKETING OF RIJEKA MUSEUMS: CURRENT ...

1. the presence and the characteristics of marketing practice in Rijeka museums;

2. the process of designing and developing museum services;

3. the acquaintance with the museum trends and opinion whether these trends influence the marketing practice.

After the introduction, a brief overview of the relevant theoretical contributions precedes the basic information about the researched museums and a detailed description of the conducted qualitative research. In the concluding part, theoretical contribution and managerial implications are defined, research limitations reported, and possible future research directions offered.

\section{THEORETICAL BACKGROUND}

Over time, the definition of a museum changed its form. In 2007, the International Council of Museums (ICOM) introduced the definition according to which "A museum is a non-profit, permanent institution in the service of society and its development, open to the public, which acquires, conserves, researches, communicates and exhibits the tangible and intangible heritage of humanity and its environment for the purposes of education, study and enjoyment" (ICOM, n.d. Museum definition).

Despite the long-standing interest of scholars in researching numerous and complex challenges for implementing, developing and improving marketing in museums (McLean 1993; Kotler and Kotler 2000; Rentschler and Hede 2007; Cole 2008; Recuero Virto, Blasco López and San-Martín 2017; Foster et al. 2020) the relevance and attractiveness of this study field are not diminishing. On the contrary, the paradigm of the economy of experience (Pine and Gilmore 2011; Lee and Smith 2015; Nowacki and Kruczek 2021) points to the growing need for a comprehensive and holistic view of museum services as experiences that will enable learning, entertainment, escape from everyday life, and aesthetics.

The museum offer should provide the visitor with an essential service through exhibitions and education that meet cultural, entertainment, and educational goals and fulfill visitors' expectations (Hume 2011). In addition, offering various other possibilities, like social events, courses, festivals, and alike has become frequent in museum practice, including virtual museum tours (Kotler et al. 2008; Leopardi et al. 2021).

Chan $(2009,176)$ points out: "a museum is the amalgam of a series of experiential encounters (tangible and intangible), and museum experiences come from service providers (quality of performance) and visitors themselves (quality of experience)". Unlike in the past, when the reaction of visitors was secondary, today museums are put in the "shoes of customers," i.e., they are focused on feedback on everything that a museum can contain, from sanitary spaces to art (DeVita 2001, 3). Thereby, realising that visitors represent the new focus of the business, the museum sector has started changing its marketing strategies by providing users with an experience in various and numerous ways (Lehman 2009). 
ToSEE - Tourism in Southern and Eastern Europe, Vol. 6, pp. 545-558, 2021.

Đ. Ozretić Došen, E. Cvetinović, T Komarac: MARKETING OF RIJEKA MUSEUMS: CURRENT ...

Komarac, Ozretić Došen and Škare (2017) affirm that the roles of museums and visitors have changed, primarily because visitors look for and want more and more unique and satisfying experiences (Chan 2009). Moreover, as consumers of cultural services, they can choose between different types of educational and/or entertainment content, between new and old media, and between physical and virtual environments. Therefore, as Camarero, Garrido and Vicente (2011) put forth, museums are subject to continuous innovation, the most common of which should include enriching existing services and advances in technology applied to create exceptional museum experiences.

\section{RIJEKA MUSEUMS}

Conditions and methods of performing museum activities in the Republic of Croatia, regardless of the type and ownership over museums, are regulated by the Law on Museums (Narodne novine 2018). In the time of research, there were six museums in Rijeka. Although their role in the traditional cultural tourism of Rijeka is indisputable, they also represent one of the foundations for the development of the insufficiently developed cultural and creative industries of Rijeka (Stipanović, Rudan and Zubović 2019), which makes them an interesting subject of research in the context of marketing in museums. Table 1 depicts visits in public museums in the period from 2017 to 2020 , showing that four out of six museums had around one million visitors in the period of four years.

Table 1: Visits to Rijeka public museums in the period from 2017 to 2020

\begin{tabular}{|c|c|c|c|c|}
\hline \multirow{2}{*}{ Museum } & \multicolumn{4}{|c|}{ Number of visitors per year } \\
\hline & 2017 & 2018 & 2019 & 2020 \\
\hline $\begin{array}{l}\text { Natural History Museum of Rijeka } \\
\text { (Prirodoslovni muzej Rijeka) }\end{array}$ & 99195 & $455913^{*}$ & N/a & 10204 \\
\hline $\begin{array}{l}\text { Museum of Modern and Contemporary Art } \\
\text { (Muzej moderne i suvremene umjetnosti) }\end{array}$ & 65009 & 64835 & N/a & 74940 \\
\hline $\begin{array}{l}\text { Rijeka City Museum (Muzej grada Rijeke) } \\
\text { Maritime and History Museum of the }\end{array}$ & 26395 & 26467 & 40143 & 7834 \\
\hline $\begin{array}{l}\text { Croatian Littoral Rijeka (Pomorski i } \\
\text { povijesni muzej Hrvatskog primorja) }\end{array}$ & 23012 & 36675 & 38375 & 17880 \\
\hline Total: & 213611 & 583890 & 78518 & 110858 \\
\hline Total all museums: & & & & 986877 \\
\hline
\end{tabular}

*Including Zrinski castle, Brod na Kup

Source: Museum Documentation Centre, Muzejska statistika, viewed 2 May 2021,

http://mdc.hr/hr/muzeji/muzejska-statistika/statistika-hrvatskih-muzeja/

Four public museums are: Rijeka City Museum, Maritime and History Museum of the Croatian Littoral Rijeka, Natural History Museum of Rijeka and Museum of Modern and Contemporary Art.

Rijeka City Museum (https://www.muzej-rijeka.hr/en/home) is a general culturalhistorical museum. It owns 14 collections and does not have a permanent but organises temporary exhibitions. 
ToSEE - Tourism in Southern and Eastern Europe, Vol. 6, pp. 545-558, 2021.

Đ. Ozretić Došen, E. Cvetinović, T Komarac: MARKETING OF RIJEKA MUSEUMS: CURRENT ...

Maritime and History Museum of the Croatian Littoral Rijeka (http://ppmhp.hr/en/) is a national museum with a permanent exhibition and offers temporary exhibitions. The content is: archaeological, ethnographic, artistic, historical-cultural, and maritimehistorical, making a total of 32 collections.

Natural History Museum of Rijeka (https://www.prirodoslovni.com/eng/program.htm) is a specialised museum that operates as a scientific and educational institution and is the only one engaged in the sea's biological and ecological research in the Primorje-Gorski Kotar County. It has 29 collections with 90,000 museum specimens (http://hvm.mdc.hr).

Museum of Modern and Contemporary Art (https://mmsu.hr/en/) is a specialised museum with a reputation as one of the most prestigious institutions in visual arts. Its collection exceeds 8,000 exhibits dating from the 19th century to the present day.

Two private museums are Peek \& Poke - Computer Museum and Peek \& Poke - Museum of Childhood. In contrast to public museums, these museums do not have public data on museum visits.

Peek \& Poke - Computer Museum (https://www.peekpoke.hr/our-story/) is a specialised museum, possessing a permanent exhibition of 1000 exhibits with approximately 300 computers and 700 calculators and other items that influenced the development of informatics.

Peek \& Poke - Museum of Childhood (https://www.peekpoke.hr/peekpoke-museum-ofchildhood). The museum materials consist of toys that generations of children have used, thematically divided into five areas.

Secondary data on museums' marketing activities were collected through field visits, using available materials found in museums, and analysing online museum platforms' activities.

Although located in the city center, Rijeka museums are poorly noticed. A tour showed a lack of signposts that would direct potential visitors to the museum; only the names displayed on the buildings indicate that there is a museum inside. Except for the Museum of Modern and Contemporary Art, all are located in the immediate vicinity forming a narrow museum circle. However, the potential of museum proximity is not appropriately used. In addition to attracting visitors, clustering (grouping) of museums can achieve many other advantages. According to van Aalst and Boogaarts (2002), the advantages are related to the establishment of joint infrastructures (parking, public transport, roads), the establishment of joint technical services and staff (maintenance, security, information reception, etc.) and the provision of commercial services (hospitality, shops, etc.).

Facebook is the most used social media platform (for all museums), followed by Instagram. The Peek \& Poke museums are, compared to others, more engaged in activities on social media. All museums have websites with information about the location, working hours, ticket prices and contacts. YouTube channels Moja Rijeka and Kanal RI (local TV station) provide the most multimedia content about current exhibitions and events. The daily press Novi List informs about museums' events under 
ToSEE - Tourism in Southern and Eastern Europe, Vol. 6, pp. 545-558, 2021.

Đ. Ozretić Došen, E. Cvetinović, T Komarac: MARKETING OF RIJEKA MUSEUMS: CURRENT ...

the column Culture. However, analysis of promotional efforts shows low level: activities in cooperation with the tourist board are modest, and the lack of promotional materials is worrying. Promotional materials in museums are brochures describing permanent and/or upcoming temporary exhibitions, future projects, and dislocated exhibitions. Museum maps were found only in two museums. The Tourist Board of the City of Rijeka advertises all museums on its website informing potential visitors about opening hours, ticket prices, offers hyperlinks to museum's websites, and brief information about each museum. Also, it promotes the "Museums Together" project - where a visitor with one purchased ticket can have an access to all Rijeka museums, individual museums in the vicinity of Rijeka, and individual institutions.

\section{RESEARCH ON MUSEUM PROFESSIONALS' ATTITUDES ABOUT MARKETING IN RIJEKA MUSEUMS AND CONTEMPORARY TRENDS IN MUSEUM MARKETING}

\subsection{Research questions}

The growing museum presence in the public focus in developed countries to redefine their role and importance for preserving living cultures exists for decades (Šola 2001). However, the level of public interest in museums in Croatia is still modest. The existing research on the application of marketing in Croatian museums (Komarac, 2013; Komarac, Ozretić Došen and Škare 2014; Komarac et al. 2017) shows that the level of integration of traditional activities of collection, research, and preservation of exhibits with the activities of their presentation to the interested public in order to create new values - learning and/or entertainment experiences, has not reached the necessary and desired level. Therefore, the first research question was posed:

1. What is the role of marketing in Rijeka museums, the level of marketing knowledge and skills of their professionals, and the respective implementation in practice?

The experience of visiting the museum is determined by the complete encounter with the museum's offer, which includes core and additional services designed in an attractive and to a targeted visitors adapted marketing mix (Hume 2011; Komarac, Ozretić Došen and Škare 2019; Ozretić Došen and Buljat 2021; Komarac and Bešlić 2021). In that vein the following research question is made:

\section{What core and additional services are offered, and how are they created?}

Furthermore, marketing trends such as digitalization, connectivity, disintermediation, customization, automation, consumer empowerment, caused by numerous and radical changes in the experiential economy, do not bypass the museums. However, successful museum business depends mainly on the museum professionals' understanding of the unique value that these trends can add to strategic and tactic marketing efforts to attract visitors and build their loyalty (Komarac, Ozretić Došen and Jurić Bulatović 2019; Komarac, Ozretić Došen and Škare 2020). Therefore, a third research question was asked: 
ToSEE - Tourism in Southern and Eastern Europe, Vol. 6, pp. 545-558, 2021.

Đ. Ozretić Došen, E. Cvetinović, T Komarac: MARKETING OF RIJEKA MUSEUMS: CURRENT ...

3. What are museum professionals' opinions and attitudes regarding contemporary trends in museum marketing?

A qualitative research approach was applied. All museums received an e-mail invitation to participate. Those that did not respond were reminded by telephone. Finally, all museums agreed to take part. In-depth, semi-structured personal interviews with five key informants (Belk 2006) representing all six museums were conducted. Interview guidelines were used. From five interviews, two were conducted with the persons in charge of the marketing, two with the general managers, and one with two museums' general manager. Respondents were guaranteed anonymity. Four out of five interviews were conducted in the museum premises. The duration of interviews was 45 to 90 minutes, depending on the complexity of the topics covered and the respondents' relaxation and cooperation. Interviews were conducted face-to-face by one researcher and were recorded. All transcripts were encrypted.

The interviewing took place before the Covid pandemic crisis, from September 2018 to May 2019. Content analysis of transcripts was performed to categorise responses regarding the three research questions-topics. In addition, the analysis included secondary written and audio-visual data from museums' internal and promotional materials for data triangulation (Bahl and Milne 2006).

\subsection{Findings and analysis}

Only two museums have a marketing department. Two respondents were female and three male. Their professional profiles are shown in Table 2.

Table 2: Professional profile of a person who performs museum marketing activities

\begin{tabular}{lcc}
\hline Professional profile & Marketing education & Marketing department in the museum \\
\hline Architect & No & No \\
Psychologist & No & Yes \\
Economist & No & No \\
Economist in tourism & No & Yes \\
Historian & No & No \\
\hline
\end{tabular}

Source: Authors' research

3.3.1. The role of marketing in museums, the level of professionals' marketing knowledge and skills, and the implementation in practice

Answers to the RQ1 reveal that respondents do not show resistance to marketing and the need for its application in museum everyday activities. Although two respondents equate it with advertising, most see marketing as a promising strategy, especially when the smaller Rijeka museums will cover a broader range of activities with the movement to new locations. 
ToSEE - Tourism in Southern and Eastern Europe, Vol. 6, pp. 545-558, 2021.

"Marketing is one of the key aspects of the museum. Maybe before, the curator was crucial in the museum and without him nothing, and now it seems to me that their role is almost equal. Marketing plays a key role in managing the process of developing new products, for which the museum is an inexhaustible source. (...) Marketing is considered important for popularising heritage and raising community awareness of its value." (M1)

Even the most critical attitude does not oppose the need for marketing activities in a museum:

"Few museums employ a marketing expert; not much attention is paid to it. (...) When it comes to marketing, it is a kind of sale, and promotion and sales altogether. (...) In my opinion, the right approach for marketers would be to have external agencies who really live on commissions, because it is a negative situation that someone gets a job as a marketing manager and it costs more money or benefits than those that come with him to the museum." (M2)

Most respondents consider marketing specialists a vital part of the museum's staff structure. However, they point to problems of difficult approval for the new employees, obsolescence of the current organisational structure that hinders the achievement of specific goals and projects, and the burden on the existing museum staff so that no one can fully dedicate to marketing. Illustrative quote is:

"The museum system, that is, the type of professions, on the one hand, has remained old, but times have changed. There are no other professions in the system, and then you cannot implement ideas. (...) Our museum has enormous potential. Unfortunately, we lack professional staff, i.e., a person from marketing. We are sure that the results would be much better reflected than at the moment when certain marketing activities are incompletely done. Sustainability and circumstances are pushing us forward, but this is impossible due to the outdated staff structure that operates on the working principle of sixty years ago. " (M1)

3.3.2. The process of designing services (core and additional ones) offered by Rijeka museums

Regarding RQ 2, all respondents stated that the process of designing museum services is internal. The focus is on a museum exhibit that gets a service upgrade based on fascinating historical, artistic content or anecdotes and finds its way to visitors. In that regard, they said:

"First, I concentrate on the exhibition to be as interesting as possible; the museum profession is practical. There should be some science, some education, and there has to be some fun. The dry line-up needs curiosities in that story, some theatrical addition. It is easier to attract interest with human destinies." (M2)

"Often, there are no marketing concepts applied in the design of the program by the curators. They think about promotion and public relations when the program is done, 
ToSEE - Tourism in Southern and Eastern Europe, Vol. 6, pp. 545-558, 2021.

Đ. Ozretić Došen, E. Cvetinović, T Komarac: MARKETING OF RIJEKA MUSEUMS: CURRENT ...

but there is no primary marketing content. For example, we prepare an artist's exhibition, and his/her works are as they are. We want him/her for some of our museum reasons and how to fit the marketing concept here now? Change that product? We cannot change its content. We can modify it but only in some marginal parts. There is this collision; we have only promotion as a tool with which we could present better that same product in public." (M3)

Table 3 summarises core, additional, and potential services (which have yet to be implemented and offered). In addition to each type of service, there is a quantitative indication of representation in museums.

Table 3: Core, additional and potential services in Rijeka museums

\begin{tabular}{llll}
\hline & Core services & Additional service & Potential services \\
\hline 1. & $\begin{array}{l}\text { Exhibitions [6/6] } \\
\text { Collection, processing, } \\
\text { storage of museum material } \\
\text { [6/6] }\end{array}$ & Museum guiding [6/6] & Catering services [6/6] \\
3. & & Concerts [6/6] & $\begin{array}{l}\text { Different music contents / } \\
\text { concerts [6/6] }\end{array}$ \\
4. & Publishing [5/6] & $\begin{array}{l}\text { Implementation of technology } \\
\text { and digital content [5/6] }\end{array}$ \\
5. & Performances [5/6] & Sale of copyrights [ 1/6] \\
6. & Space rental [4/6] & Catering with gastronomic \\
7. & Seminars [3/6] [1/6] \\
8. & Filmed material projections [3/6] & Yoga [1/6] \\
9. & Organising symposia [2/6] & \\
10. & Birthday celebrations [2/6] & \\
11. & Rental of museum exhibits [1/6] & \\
12. & Organising excursions [1/6] & \\
13. & Organisation round tables / & \\
14. & tribunes [1/6] & \\
15. & Welcome drink [1/6] [1/6] & \\
\hline & Skating school [1/6] & \\
\hline
\end{tabular}

Source: Authors' research

Illustrative quotes are:

1. Core services:

"Museum's role is to show exhibitions, but it is just one of the important roles. The first one is to collect material. In fact, all museums are obliged to collect material; it is their mission to deal with it, to process it and arrange, to research what a particular object means in a certain context, and finally to prepare and show exhibitions." (M2)

2. Additional services:

"About 150 workshops and 200 celebrations of educational birthdays, conducted as an educational workshop (...) We also have activities for different age groups, the elderly and/or adults (...) We organise lectures, seminars, day trips to the field (...). 
ToSEE - Tourism in Southern and Eastern Europe, Vol. 6, pp. 545-558, 2021.

Đ. Ozretić Došen, E. Cvetinović, T Komarac: MARKETING OF RIJEKA MUSEUMS: CURRENT ...

We do not have space for additional content. As for concerts and performances, we host it all." (M5)

3. Potential services:

"We intend to introduce yoga; in my opinion, the museum should be so much open. The more these contents happen in the museum, the more people will see the museum exhibits (...) Catering facilities and music events are great and very important for two-way success." (M1)

"The new project includes many visual, technological, tactile solutions to experience the exhibition and not just looking at the exhibits." (M4)

Most museums had programs in which visitors could get involved and have an impact, although minimal, mainly modifying the already existing offering.

"By listening to them, we have implemented most the input received, that is, the suggestions from the audience in the projects we run. We reshaped them to get the final product. (...) We have programs through which visitors make something creative; of course, before that, they are educated, and then they have exhibitions with us." (M5)

3.3.3. Museum professionals' opinions and attitudes about contemporary trends in museum marketing

The third research question, in addition to focusing on the respondents' familiarity with contemporary trends and attitudes about them, also referred to activities that enrich the museums' offer and visitors' experiences, such as catering facilities, different artistic performances, museum shops, and the application of technological achievements (virtual museums, audio guides, mobile applications, etc.).

A positive attitude towards the museum as a place of entertainment and education was found in all museum. Respondents stated:

"It needs to be absolutely connected. For me, a museum is a place of public gathering, entertainment and education. ”(M1)

"I think it's a good combination of two activities that it can coexist with each other and that museums that, as much as they have that educational side, also have that kind of consumer-entertainment side." (M3)

All respondents pointed out a souvenir shop, which by law must contain different types of exhibits' replicas as a product of the museum. The problem is the space; most museums do not have adequate conditions. Also, as the exhibitions change, this represents a specific challenge for a museum shop. Employees (in two museums), students (in two museums), a museum employee who performs other tasks (in one museum) work in souvenir shops. One museum does not have a permanent souvenir shop, neither a person dedicated to sales activities. Most of the respondents consider the possibility of expanding the offer of a souvenir shop and online selling necessary and 
ToSEE - Tourism in Southern and Eastern Europe, Vol. 6, pp. 545-558, 2021.

Đ. Ozretić Došen, E. Cvetinović, T Komarac: MARKETING OF RIJEKA MUSEUMS: CURRENT ...

desirable, but as one of them stressed, there are difficulties related to the legal frame in that domain. Museum professionals were a bit sceptical regarding quick changes to enable the improvements.

\section{DISCUSSION}

Research has shown that marketing is predominantly identified with promotion and partly seen as a channel for attracting funding for museum activities within international and national projects. Although none of the respondents has a formal marketing education, most of them attended courses in related areas, such as public relations and web design. There has been a lack of employees in museums, so some perform multiple jobs, such as, e.g., pedagogue and public relations. Despite that, all respondents have a favorable opinion on marketing and believe that it needs to be implemented, including the most restrained respondent stating that it is enough to entrust marketing to an external marketing agency. These findings are in line with the previous study conducted by Komarac et al. (2014), who discovered positive perceptions about marketing and the predominant association of promotion. Obstacles to more comprehensive implementation include complicated and discouraging administrative procedures regarding permission for new employment, an outdated organizational structure that cannot keep pace with current demands, the work overload of existing employees, and an overall obsolescence/inconsistency of the system that hinders the achievement of specific museum goals.

When designing services, the primary focus is on collections, followed by a focus on visitors. Nevertheless, museums are proactive in their efforts to reach the public. In the visitors' structure, students, schoolchildren, and children accompanied by parents are the most represented, and during the summer tourists. The young population is essential for creating "... a sensibility towards art and museums, thus giving museums an audience for the future" (M2). Direct communication and social networks are used to monitor the needs and satisfaction of visitors and, to a lesser extent, surveys and books of impressions.

The findings corroborate those of previous research (Colbert 2003; De Rojas and Camarero 2008; Nowacki and Kruczek 2021) that the experience of visiting a museum must provide more than a mere tour of the exhibits. The typical services development process in Rijeka museums includes the sequence: 1) Designing exhibitions, 2) Adding exciting and entertaining content that complements the original idea of the exhibition, 3) Presentation to the public, and 4) Possible changes and adjustments based on suggestions and/or criticism of visitors. Such a process shows a more thorough understanding of visitors' expectations and the need to create additional opportunities to communicate and deliver the exhibition's value as a museum's service.

Results reveal that spatial conditions represent a significant problem. For example, the space for the exhibition is not large enough (in four out of six museums) to allow the realisation of most of the programs and simultaneously receive many visitors. It also represents an obstacle for implementing additional services (e.g., more advanced museum shops, catering facilities). However, museum professionals are aware of the 
ToSEE - Tourism in Southern and Eastern Europe, Vol. 6, pp. 545-558, 2021.

Đ. Ozretić Došen, E. Cvetinović, T Komarac: MARKETING OF RIJEKA MUSEUMS: CURRENT ...

potentials of those services for coping with the constraints of financing institutions of culture and arts, which is in line with the research results reported by Komarac et al. (2019).

Ticket prices are tailored to the target groups and types of exhibitions. As they still do not represent a significant source of income, museums often have an "open door" events or opportunities for free visits to exhibitions. In marketing communications, social media (Facebook and Instagram), press conferences, radio, and television advertising are used. Respondents showed restraint regarding satisfaction with the Rijeka Tourist Board level of communication efforts and activities.

At the time of the research, respondents were not satisfied with technological capabilities that can enrich the visitor's experience. For example, audio guides and mobile applications existed in only one museum, QR codes in two. Likewise, only one museum had a virtual museum. As a fundamental obstacle for more intensive implementation, which they consider necessary, the respondents mentioned the frequency of changes in the museum's exhibits. They were aware of the technological changes and willing to implement them. Virtual museums are considered a necessary step forward, also seen as one of the potential practical promotional tools. No respondent feared that a virtual museum would cannibalise on-site visits of the premises. These findings are not surprising; they sustain previously uncovered differences regarding museums' technological capabilities to provide interactive experiences (Evrard and Krebs 2018). Moreover, since museums in developing countries (Komarac et al., 2020), and developed countries like Italy, too (Romolini et al. 2020) still depend on public and government funding, their resources for implementing and maintaining interactive technology are limited.

Great hopes were placed in the project Rijeka - European Capital of Culture 2020, as an opportunity to improve working conditions, equipping with technological capabilities, and introducing new content. Also, to improve the conditions for earning income through the museum activities, the respondents considered it necessary to change/restructure the current legal framework and regulations.

\section{CONCLUSION AND RECOMMENDATION}

Irrespective of the existing differences found in the respondents' perceptions, it may be concluded that Rijeka museum professionals are aware of the need to offer an attractive service composed of education, entertainment, and experience. A significant overall finding of the research indicates that there are no longer museum professionals' prejudices towards marketing which will endanger its application, but an evident dissatisfaction due to many obstacles to creating conditions for the more intensive implementation of marketing activities in museums.

A focused approach to museum marketing is crucial, as the consumption of cultural services faces many challenges. These challenges become more and more complex in the current context of a coronavirus-induced pandemic which endangers museums to a great extent. In this sense, the slogan by which the International Council of Museums 
ToSEE - Tourism in Southern and Eastern Europe, Vol. 6, pp. 545-558, 2021.

Đ. Ozretić Došen, E. Cvetinović, T Komarac: MARKETING OF RIJEKA MUSEUMS: CURRENT ...

(ICOM) calls for World Museum Day in 2021 is: "The Future of Museums: Recover and Reimagine," stating that it "will focus on rethinking the museum of the future to meet the challenges of the present" (ICOM, International museum day, 2021).

The paper makes a contextual contribution to the marketing theory and offers one more platform for starting new research on museum marketing for all interested in this particular topic. Furthermore, it enriches the scientific bibliography from the field. Finally, for all involved in museum management (in public entities and museums), the research may serve as a piece of up-to-date information about the areas which call for improvement.

The limitations are related to the nature of qualitative research and the fact that it is based on specific data, in this case, on the subjective respondents' perceptions. Furthermore, the credibility of the interpretation of such data depends on its accuracy and completeness. Therefore, it is necessary to consider results' exclusively indicative values without the possibility of generalisation.

One specific recommendation for future research on the marketing of Rijeka museums is replicating research soon after the completion of project Rijeka - European Capital of Culture 2020, despite all the problems that have occurred in the project's implementation due to the coronavirus pandemic. The research could also be replicated during or after the coronavirus pandemic to corroborate its impact. In addition, researching the perceptions of domestic and or foreign visitors and the perceptions of various stakeholders of the local community on the marketing of Rijeka museums is needed.

\section{REFERENCES}

Bahl, S. and Milne, G.R. (2006) „Mixed methods in interpretive research: an application to the study of the self concept", in Belk, R.W. (Ed.), Handbook of Qualitative Research Methods in Marketing, Edward Elgar Cheltenhamm, UK.

Belk, R.W. (Ed.) (2006), Handbook of Qualitative Research Methods in Marketing, Edward Elgar Cheltenhamm, UK.

Camarero, C., Garrido, M.J. and Vicente, E. (2011), "How cultural organisations' size and funding influence innovation and performance: the case of museums", Journal of Cultural Economics, Vol. 35, pp 247-266. https://doi.org/10.1007/s10824-011-9144-4

Camarero, C., Garrido, M.J. and Vicente, E. (2015), "Achieving effective visitor orientation in European museums. Innovation versus custodial”, Journal of Cultural Heritage, Vol. 16, No. 2, pp. 228-235. https://doi.org/10.1016/j.culher.2014.05.006

Chan, J.K.L. (2009). The Consumption of Museum Service Experiences: Benefits and Value of Museum Experiences. Journal of Hospitality Marketing \& Management, Vol. 18, No. 2-3, pp. 173-196. https://doi.org/10.1080/19368620802590209

Colbert, F. (2003), Entrepreneurship and leadership in marketing arts", International Journal of Arts Management, Vol. 6, No. 1, pp. 30-39. https://www.jstor.org/stable/41064806

Cole, D. (2008), "Museum marketing as a tool for survival and creativity: the mining museum perspective", Museum Management and Curatorship, Vol. 23, No. 2, pp. 177-192. https://doi.org/10.1080/09647770701865576

De Rojas, C. and Camarero, C. (2008), "Visitors' experience, mood and satisfaction in a heritage context: Evidence from an interpretation center", Tourism Management, Vol. 29, No. 3, pp. 525-537. https://doi.org/10.1016/j.tourman.2007.06.004

DeVita, M.C. (2001), "Introduction", in Service to People: Challenges and Rewards How museums can become more visitor-centered, Lila Wallace-Reader's Digest Fund, New York, NY. 
ToSEE - Tourism in Southern and Eastern Europe, Vol. 6, pp. 545-558, 2021.

Đ. Ozretić Došen, E. Cvetinović, T Komarac: MARKETING OF RIJEKA MUSEUMS: CURRENT ...

Evrard, Y. and Krebs, A. (2018), "The authenticity of the museum experience in the digital age: the case of the Louvre", Journal of Cultural Economics, Vol. 42, No. 3, pp. 353-363. https://doi.org/10.1007/s10824-017-9309-X

Foster, S., Fillis, I., Lehman, K. and Wickham, M. (2020), "Investigating the relationship between visitor location and motivations to attend a museum", Cultural Trends, Vol. 29, No. 3, pp. 213-233. https://doi.org/10.1080/09548963.2020.1782172

Gilmore, A. and Rentschler, R. (2002), Changes in museum management: A custodial or marketing emphasis? Journal of Management Development, Vol. 21, No. 10, pp. 745-760. https://doi.org/10.1108/02621710210448020

Hume, M., (2011), "How Do We Keep Them Coming?: Examining Museum Experiences Using a Services Marketing Paradigm”, Journal of Nonprofit \& Public Sector Marketing, Vol. 23, No. 1, pp. 71-94. https://doi.org/10.1080/10495142.2011.548759

ICOM, n.d., International Museum day 2021, viewed 4 May 2021, https://icom.museum/en/news/internationalmuseum-day-2021/

ICOM, n.d., Museum definition, viewed 6 February 2018, http://archives.icom.museum/hist_def_eng.html

Komarac, T. (2013), ,Marketing usluga zagrebačkih muzeja“, Specijalistički poslijediplomski rad. Ekonomski fakultet, Zagreb.

Komarac, T. and Bešlić S. (2021), "Uvid u percepciju muzeja i mogućnosti poboljšanja usluge muzeja: perspektiva studenata“, Ekonomski pregled, Vol. 72, No. 3, pp. 358-376. https://doi.org/10.32910/ep.72.3.2

Komarac, T., Ozretić Došen, Đ. and Škare, V. (2020), "Managing edutainment and perceived authenticity of museum visitor experience: Insights from qualitative study" Museum Management and Curatorship, Vol. 35, No. 2, pp. 160-181. https://doi.org/10.1080/09647775.2019.1630850

Komarac, T., Ozretić Došen, Đ. and Jurić Bulatović, V. (2019), "The role of special event in attracting museum visitors and popularizing museums", ToSEE - Tourism in Southern and Eastern Europe 2019 Conference Proceedings, Zadel, Z., Smolčić Jurdana, D. (ed.), Faculty of Tourism and Hospitality Management, University of Rijeka, Opatija, pp. 375-387. https://doi.org/10.20867/tosee.05.38

Komarac, T., Ozretić Došen, Đ. and Škare, V. (2019), "The Role of the Museum Shop: Eliciting the Opinions of Museum Professionals”, International Journal of Arts Management, Vol. 21, No. 3, pp. 28-41.

Komarac, T., Ozretić-Došen, Đ. and Škare, V. (2017), "Understanding competition and service offer in museum marketing", Academia Revista Latinoamericana de Administracion, Vol 30, No. 2, pp. 215-230. https://doi.org/10.1108/ARLA-07-2015-0159

Komarac, T., Ozretić-Došen, Đ. and Škare, V. (2014), "Museum marketing and virtual museums in 21st century: Can museums survive without it?", 5th EMAC Regional Conference - Marketing Theory Challenges in Emerging Markets/ Maja Szymura-Tyc (Ed.), Katowice: University of Economics Katowice, pp. 105-112.

Kotler, G. N., Kotler, P. and Kotler, I. W. (2008), Museum marketing and strategy: Designing Missions, Building Audiences, Generating Revenue and Resources, Jossey-Bass, San Francisco, CA.

Kotler, N. and Kotler P. (2000), "Can Museums be all Things to All People?: Missions, Goals, and Marketing's Role", Museum Management and Curatorship, Vol. 18, No. 3, pp. 271-287. https://doi.org/10.1080/09647770000301803

Lee, H.M. and Smith, S.L.J. (2015), “A Visitor Experience Scale: Historic Sites and Museums”, Journal of China Tourism Research, Vol. 11, No. 3, pp. 255-277. https://doi.org/10.1080/19388160.2015.1083499

Lehman, K. (2009), “Australian Museum and the Modern Public: A Marketing Context”, The Journal of Arts Management, Law, and Society, Vol. 39, No. 2, pp. 87-100. https://doi.org/10.3200/JAML.39.2.87100

Leopardi, A., Ceccacci, S., Mengoni, M., Naspetti, S., Gambelli, D., Ozturk, E. and Zanoli, R. (2021), "Xreality technologies for museums: a comparative evaluation based on presence and visitors experience through user studies", Journal of Cultural Heritage, Vol. 47, No. January-February, pp. 188-198. https://doi.org/10.1016/j.culher.2020.10.005

McLean, F. (1993), "Marketing in museums: A contextual analysis", Museum Management and Curatorship, Vol. 12, No. 1, pp. 11-27.

Narodne novine, (2018)., Zakon o muzejima, viewed 29th July, 2021, https://narodnenovine.nn.hr/clanci/sluzbeni/2018_07_61_1267.html

Nowacki, M. and Kruczek, Z. (2021), "Experience marketing at Polish museums and visitor attractions: the co-creation of visitor experiences, emotions and satisfaction", Museum Management and Curatorship, Vol. 36, No. 1, pp. 62-81. https://doi.org/10.1080/09647775.2020.1730228

Ozretić Došen, Đ. and Buljat A. (2021), "Marketing usluga dominikanskih muzeja u Republici Hrvatskoj", Ekonomski pregled, Vol, 72, No. 3, pp. 224-248. https://doi.org/10.32910/ep.72.2.4

Pine, B.J. and Gilmore, J.H. (2011), The Experience economy, Harvard Business Review Press, Boston, MA. 
ToSEE - Tourism in Southern and Eastern Europe, Vol. 6, pp. 545-558, 2021.

Đ. Ozretić Došen, E. Cvetinović, T Komarac: MARKETING OF RIJEKA MUSEUMS: CURRENT ...

Recuero Virto, N., Blasco López, M.F. and San-Martín, S. (2017), "How can European museums reach sustainability?", Tourism Review, Vol. 72, No. 3, pp. 303-318. https://doi.org/10.1108/TR-03 2017-0038

Rentschler, R. and Hede, A.M. (2007), Museum marketing: competing in the global marketplace, ButterworthHeinemann, Oxford.

Romolini, A., Fissi, S., Gori, E. and Contri, M. (2020), "Financing Museums: Towards Alternative Solutions? Evidence from Italy", in Piber, M. (Ed.), Management, Participation and Entrepreneurship in the Cultural and Creative Sector, Springer. Cham, Switzerland, pp. 11-32.

Stipanović, C., Rudan, E., and Zubović, V. (2019), "Cultural and creative industries in urban tourism innovation - the example of the city of Rijeka", ToSEE - Tourism in Southern and Eastern Europe 2019 Conference Proceedings, Zadel, Z., Smolčić Jurdana, D. (ed.), Faculty of Tourism and Hospitality Management, University of Rijeka, Opatija, pp. 665-666. https://doi.org/10.20867/tosee.05.47

Šola, T. (2001), Marketing u muzejima ili o vrlini i kako je obznaniti, Hrvatsko muzejsko društvo, Zagreb.

van Aalst, I. and Boogaarts, I. (2002), "From museum to mass entertainment: The evolution of the role of museums in cities", European Urban and Regional Studies, Vol. 9, No. 3, pp. 195-209. https://doi.org/10.1177/096977640200900301

Đurđana Ozretić Došen, PhD, Full Professor

University of Zagreb, Faculty of Economics \& Business

Marketing department

Trg J. F. Kennedyja 6, 10000 Zagreb, Croatia

$+385-1-2383463$

dozretic@efzg.hr

Emanuela Cvetinović, Mag. oec.

Alumni of Faculty of Economics \& Business, University of Zagreb

emanuela.cvetinovic@gmail.com

Tanja Komarac, $\mathrm{PhD}$, Postdoctoral Researcher

University of Zagreb, Faculty of Economics \& Business

Marketing department

Trg J. F. Kennedyja 6, 10000 Zagreb, Croatia

+385-99-2635103

tkomarac@net.efzg.hr 